\title{
CONSIDERAȚII CU PRIVIRE LA INTERACȚIUNILE GRÂU - PATOGENI FUNGI ÎN CONTEXTUL SCHIMBĂRILOR CLIMATICE
}

\author{
Lupașcu G., Gavzer S. \\ Institutul de Genetică, Fiziologie şi Protecţie a Plantelor, \\ Chişinău, Republica Moldova, galinalupascu51@gmail.com
}

https://doi.org/10.53040/9789975347204.06

\begin{abstract}
It was established that the environmental conditions strongly influence the fungal spectrum that causes the root rot of the stem base to common wheat in the conditions of the Republic of Moldova. In more severe conditions (high temperature, drought) the incidence of Fusarium equiseti increases. The interaction of common wheat with one of the causative agents of stem rot $-F$. oxysporum is determined by the combination, the orientation of the cross to obtain $\mathrm{F}_{1}$ hybrids, the temperature factor, which has a direct impact on seedling growth and transgressive potential of $\mathrm{F}_{2}$ segregating populations, a phenomenon with major importance for the improvement programs.
\end{abstract}

Key word: wheat, fungi, root ror, environmental factors, temperature, hibrids, reaction.

\section{Introducere}

Schimbările de mediu la nivel global provocate de activităţile naturale și umane, în special de revoluția industrială, s-au accelerat în ultimii 200 de ani. Conform unor opinii, creșterea gazelor cu efect de seră va continua să majoreze temperatura globală și să afecteze rezervele de apă în secolul XXI. Bolile plantelor sunt profund influențate de mediu: o gazdă sensibilă nu va fi infectată de un agent patogen virulent dacă condițiile de mediu nu sunt favorabile bolii. Modificarea concentrației de $\mathrm{CO}_{2}$, temperaturii și accesibilității apei, preconizată să se producă în acest secol, poate avea efecte pozitive, neutre sau negative asupra dezvoltării bolilor de plante, deoarece fiecare fitopatosistem (mediu - gazdă - patogen) poate răspunde diferit la aceste variații. Din considerente genetice, de mediu și tradiție, nu toate culturile au aceeași importanță în alimentația umană, zece din ele ocupând circa $58 \%$ din suprafața totală cultivată la nivel global. În ceea ce privește securitatea alimentară globală, doar patru culturi - orezul, grâul, porumbul, soia contribuie cu până la $50 \%$ din consumul zilnic de calorii umane la nivel mondial. Grâul se cultivă în lume pe o suprafață de $220.42 \mathrm{mln}$ ha, având o producție de 729, $01 \mathrm{mln} \mathrm{t}$ [12].

Conform unor date, creșterea preconizată a temperaturii și schimbările regionale ale asigurării cu apă vor schimba zonele de cultivare a plantelor agricole, populațiile de vectori și patogeni care provoacă boli [5]. A fost observată deplasarea distribuției agenților patogeni și a dăunătorilor către poli, pe măsură ce temperatura globală crește [2]. Se prevede că până în 2050, productivitatea culturilor va scădea în întreaga lume, în special în cele mai sărace și mai vulnerabile țări $[3,13]$. 
Pentru fiecare interacțiune plantă-patogen, există un interval optim de temperatură la care se dezvoltă boala [7]. S-a constatat că fluctuaţia frecvenței speciilor de Fusarium cu severitate înaltă pentru grâu $-F$. oxysporum, $F$. merismoides, $F$. sambucinum pe durata sezonului de vegetație depinde mult de temperatură și umiditate. Totodată, umiditatea ridicată a contribuit la sporirea contaminării cu Fusarium spp. [15].

Se anticipează că creșterea temperaturii globale va modifica cel mai probabil distribuția regională în care o cultură este susceptibilă la un anumit agent patogen. Pentru zonele din afara tropicelor, o tendinţă globală este prevalența supraacumulării inoculelor patogene pentru următorul sezon de creștere a culturilor, cu potențial pentru epidemii mai severe și frecvente [8]. Acest lucru va fi deosebit de relevant pentru agenții patogeni care posedă deja structuri supraviețuitoare cu toleranță la frig, căldură sau la desicare, dintre care unele pot dura câțiva ani, chiar și în condiții severe [11]. Un alt rezultat al încălzirii temperaturilor este că tulpinile noi de patogen mai bine adaptate la aceste temperaturi pot deveni prevalente.

Cercetările de bază cu privire la modul în care temperatura, umiditatea și diverse stresuri abiotice reduc semnalizarea imunitară a plantelor vor identifica, probabil, puncte vulnerabile pentru mediu în sistemul imunitar al plantelor. Astfel de cunoștințe vor servi ca bază pentru dezvoltarea unei noi generații de soiuri de plante în care sistemul imunitar al plantelor este mai rezistent la fluctuațiile de mediu [14]. Viitoarele programe de ameliorare a soiurilor îmbunătățite ar trebui să ia în calcul toleranța abiotică, creșterea și variabilitatea rezistenței biotice care favorizează imunitatea plantelor și defavorizează virulența patogenă [12].

Scopul prezentelor cercetări a constat în stabilirea influenței unor factori de mediu asupra complexului fungic care produce putrezirea bazei tulpinii la grâul comun de toamnă și potenţialului transgresiv al plantelor în populațiile segregante $F_{2}$.

\section{Material și metode}

Izolarea fungilor din plante de grâu cu semne de boală la baza tulpinii, s-a produs pe mediu Potatoe Dextrosis Agar [17]. Identificarea speciilor de fungi a fost efectuată în baza analizelor macro- şi microscopice $[1,16]$. Indicele de diversitate a fungilor s-a calculat cu ajutorul formulei Margalef [9]: $\mathrm{D}_{\mathrm{Mg}}=\mathrm{S}-1 / \mathrm{ln} \mathrm{N}(\mathrm{S}$ - numărul speciilor, $\mathrm{N}$ - numărul total al izolatelor), iar indicele de dominanţă - în baza formulei Berger-Parker [4]: $\mathrm{d}=\mathrm{N} \max _{\text {ax }} / \mathrm{N}(\mathrm{N}$ max - numărul de izolate al speciei dominante, $\mathrm{N}$ - numărul total al izolatelor).

Filtratul de cultură (FC) Fusarium oxysporum s-a preparat în baza mediului lichid nutritiv Cszapek [17]. Boabele de grâu au fost menținute în filtrat de cultură timp de 18 ore, apoi cultivate în cutii Petri la: 1) temperatură suboptimală $15-17^{\circ} \mathrm{C}$ (I) timp de 6 zile și 2) alternanță de temperatură $15-17^{\circ} \mathrm{C} / 8-9^{\circ} \mathrm{C} / 15-17^{\circ} \mathrm{C}$ (II), câte 2 zile fiecare. În calitate de indici biometrici ai creșterii plantulelor au servit lungimea rădăciniței embrionare și a tulpiniței. Efectul reciprocității la hibrizii omologi $\mathrm{F}_{1}$ a fost stabilit conform autorului [10], iar gradul $\left(\mathrm{T}_{\mathrm{g}}\right)$ și frecvența transgresiilor $\left(\mathrm{T}_{\mathrm{f}}\right)$ - conform [18].

\section{Rezultate și discuții}

Izolarea și identificarea fungilor care produc putrefacția bazei tulpinii plantelor de grâu în condițiile noastre a permis să constatăm că speciile Fusarium, Drechslera Alternaria au fost prevalente în complexul agenților cauzali ai maladiei. De menționat însă că în anii de studiu (2017-2020) diversitatea speciiilor a variat în limitele 1,23-2,87, iar nivelul de dominanță a speciei majoritare - 0,23-0,41 (tab. 1). 
Tabelul 1. Diversitatea fungilor - agenți cauzali ai putrezirii rădăcinii plantelor de grâu

\begin{tabular}{|c|c|c|c|}
\hline An, num. izolate & Diversitate $\left(\mathrm{D}_{\mathrm{Mg}}\right) /$ dominanță $(\mathrm{d})$ & Nivel & Specie dominantă \\
\hline \multirow{2}{*}{$\begin{array}{c}2017 \\
\mathrm{n}=131\end{array}$} & Margalef $\left(\mathrm{D}_{\mathrm{Mg}}\right)$ & 1,23 & \multirow{2}{*}{$\begin{array}{c}F . \text { gibbosum } \\
\text { equiseti })\end{array}$} \\
\hline & Berger-Parker (d) & 0,41 & \\
\hline \multirow{2}{*}{$\begin{array}{c}2018 \\
\mathrm{n}=185\end{array}$} & Margalef $\left(\mathrm{D}_{\mathrm{Mg}}\right)$ & 2,87 & \multirow[t]{2}{*}{ D. sorokiniana } \\
\hline & Berger-Parker $(\mathrm{d})$ & 0,23 & \\
\hline \multirow{2}{*}{$\begin{array}{c}2019 \\
n=214\end{array}$} & Margalef $\left(\mathrm{D}_{\mathrm{Mg}}\right)$ & 2,05 & \multirow[t]{2}{*}{ D. sorokiniana } \\
\hline & Berger-Parker (d) & 0,38 & \\
\hline \multirow{2}{*}{$\begin{array}{c}2020 \\
\mathrm{n}=312\end{array}$} & Margalef $\left(\mathrm{D}_{\mathrm{Mg}}\right)$ & 2,61 & \multirow{2}{*}{$\begin{array}{c}F . \text { gibbosum }(F . \\
\text { equiseti })\end{array}$} \\
\hline & Berger-Parker (d) & 0,35 & \\
\hline
\end{tabular}

În anul 2017, marcat de temperaturi foarte ridicate, și în special în 2020 caracterizat prin condiții secetoase, în complexul fungic a predominat specia $F$. gibbosum $(F$. equiseti) care conține în abundență lanțuri de clamidospori, deosebit de rezistenți la condiții nefavorabile.

Autorii [6] au constatat că severitatea petelor pe frunze la unele crucifere, cauzate de F. equiseti ( $F$. gibbosum) a fost în creștere la concentrația de 850 ppm $\mathrm{CO}_{2}$ în aer și temperaturi cuprinse între 22 și $30^{\circ} \mathrm{C}$, ceea ce oferă sprijin ipotezei că răspândirea recentă a acestui agent patogen la unele gazde noi este probabil legată de schimbările climatice, ca urmare a creșterii temperaturilor și nivelului de $\mathrm{CO}_{2}$.

S-a constatat că la hibrizii omologi $F_{1}$ se manifestă deosebiri pronunțate în vederea influenței formelor parentale asupra creșterii rădăciniței și tulpiniței în ambele condiții de creștere și în ambele variante - martor, FC. De exemplu, la hibrizii Moldova 16 x Moldova 11/Moldova 11 x Moldova 16 a sporit influența factorului matern (semnul "minus") în condiții de alternanță de temperatură. La alte 2 combinații a predominat infliența paternă (semnul "plus") (tab. 2).

Tabelul 2. Efectul reciprocităţii pentru unele caractere cantitative la hibrizii $\mathrm{F}_{1}$ de grâu comun sub influenţa filtratului de cultură $F$. oxysporum

\begin{tabular}{|c|c|c|c|c|c|}
\hline \multirow[t]{2}{*}{ Hibrid $F_{1}$} & \multirow[t]{2}{*}{ Variantă } & \multicolumn{2}{|c|}{ Temperatura $15-17^{\circ} \mathrm{C}$} & \multicolumn{2}{|c|}{$\begin{array}{c}\text { Temperatura } 15-17 / 8-9 / 15- \\
17^{\circ} \mathrm{C} \\
\end{array}$} \\
\hline & & $\begin{array}{l}\text { Lungimea } \\
\text { rădăcioarei }\end{array}$ & $\begin{array}{l}\text { Lungimea } \\
\text { tulpiniței }\end{array}$ & $\begin{array}{l}\text { Lungimea } \\
\text { rădăcioarei }\end{array}$ & $\begin{array}{l}\text { Lungimea } \\
\text { tulpiniței }\end{array}$ \\
\hline \multirow{2}{*}{$\begin{array}{l}\text { L Bas./ Moldova } 30 \\
\text { x L Mold.30/M3 }\end{array}$} & Martor & $-2,21$ & $+4,13$ & $+0,87$ & $+1,59$ \\
\hline & $\mathrm{FC}$ & $+1,29$ & $+1,06$ & $+2,03$ & $+1,53$ \\
\hline \multirow{2}{*}{$\begin{array}{l}\text { Moldova } 16 \quad \mathrm{x} \\
\text { Moldova } 11\end{array}$} & Martor & $-0,09$ & $-0,62$ & $+0,29$ & $-1,37$ \\
\hline & $\mathrm{FC}$ & $-1,74$ & $-0,51$ & $-10,5$ & $-3,47$ \\
\hline \multirow{2}{*}{$\begin{array}{l}\text { Basarabeanca } \quad \text { X } \\
\text { Mold.30/M3 }\end{array}$} & Martor & $+0,79$ & $+0,60$ & $+0,77$ & $+0,76$ \\
\hline & $\mathrm{FC}$ & $+0,47$ & $+0,49$ & $+0,01$ & $-0,28$ \\
\hline
\end{tabular}

În ceea ce privește capacitatea de manifestare a formelor transgresive la interacțiunea grâului cu $F$. oxysporum, s-a constatat că aceasta depinde de combinație, orientarea încrucișării, variantă, factorul de temperatură. În condiții de alternanță de temperatură la combinația Moldova 11 x Moldova 16 s-a înregistrat cel mai înalt nivel al transgresiilor positive, atât în condiții optime cât și cu FC (tab. 3). 
Tabel 3. Manifestarea transgresiilor în populațiile $\mathrm{F}_{2}$ de grâu la interacțiunea cu $F$. oxysporum

\begin{tabular}{|l|c|c|c|c|c|c|c|c|}
\hline \multirow{2}{*}{ Combinație $\mathrm{F}_{2}$} & \multicolumn{2}{|c|}{ Martor } & \multicolumn{2}{c|}{$\begin{array}{c}\text { FC F. } \\
\text { oxysporum }\end{array}$} & \multicolumn{2}{c|}{ Martor } & \multicolumn{2}{c|}{$\begin{array}{c}\text { FC F. } \\
\text { oxysporum }\end{array}$} \\
\cline { 2 - 9 } & $\mathrm{T}_{\mathrm{g}}, \%$ & $\mathrm{~T}_{\mathrm{f}} \%$ & $\mathrm{~T}_{\mathrm{g}} \%$ & $\mathrm{~T}_{\mathrm{f}}, \%$ & $\mathrm{~T}_{\mathrm{g}}, \%$ & $\mathrm{~T}_{\mathrm{f}}, \%$ & $\mathrm{~T}_{\mathrm{g}}, \%$ & $\mathrm{~T}_{\mathrm{f}}, \%$ \\
\hline \multicolumn{3}{|c|}{$15-17^{\circ} \mathrm{C}$} & \multicolumn{3}{c|}{$15-17 / 8-9 / 15-17^{\circ} \mathrm{C}$} \\
\hline L. Bas./M 30 x M/M3 & 0,0 & 1,7 & 7,5 & 20,8 & $-11,2$ & 6,4 & $-14,7$ & 0,0 \\
\hline M/M3 x L. Bas./M30 & 2,9 & 3,4 & 17,1 & 20,8 & $-6,2$ & 12,7 & $-13,0$ & 0,0 \\
\hline Mold. 16 x Mold. 11 & 3,4 & 1,7 & $-11,4$ & 0,0 & $-10,9$ & 0,0 & 0,3 & 12,3 \\
\hline Mold. 11 x Mold. 16 & $-10,9$ & 0,0 & 10,6 & 10,3 & 19,3 & 75,8 & 9,3 & $\mathbf{6 8 , 6}$ \\
\hline Bas. X M/M3 & $-27,5$ & 0,0 & $-2,3$ & 9,1 & $-13,2$ & 0,0 & $-23,0$ & 0,0 \\
\hline M/M3 x Bas. & 14,9 & 5,0 & 3,5 & 27,5 & $-2,7$ & 0,8 & $-9,5$ & 0,0 \\
\hline
\end{tabular}

\section{Concluzii}

1. Condițiile ambientale înfluențează puternic spectrul fungic care produce putrezirea bazei tulpinii la grâul comun în condițiile Republicii Moldova, ceea ce urmează a fi luat în considerare la elaborarea măsurilor de protecție a acestei culturi. În condiții mai severe (temperatură ridicată, secetă) crește incidența speciei $F$. gibbosum ( $F$. equiseti)

2. Interacțiunea grâului comun cu unul din agenții cauzali a putrefacției bazei tulpinii $F$. oxysporum este determinată de combinație, orientarea încrucișării la obținerea hibrizilor $\mathrm{F}_{1}$, factorul de temperatură, ceea ce are un impact direct asupra creșterii plantulelor și potenţialului transgresiv al populațiilor segregante $F_{2}$, fenomen de importanță majora pentru eficientizarea programelor de ameliorare.

\section{Bibliografie}

1. Barnet H.L., Hunter B.B. Illustrated genera of imperfect fungi. Fourth edition. St. Paul, Minn.: APS Press, 1998. 218 p.

2. Bebber D.P., Ramotowski M.A.T., Gurr S.J. Crop pests and pathogens move polewards in a warming world. In: Nat. Clim. Change, 2013, 3, p. 985-988.

3. Bierbaum R.M., Fay M., Ross-Larson B., editors. World Bank Group. World development report 2010: Development and climate change. Washington: World Bank Group, 2009.

4. Caruso T., Pigino G., Bernini F. et al. The Berger-Parker index as an effective tool for monitoring the biodiversity of disturbed soils: A case study on Mediterranean oribatid (Acari: Oribatida) assemblages. In: Biodiversity and Conservation, 2007, 16, p. 3277-3285.

5. Chakraborty S. Migrate or evolve: options for plant pathogens under climate change. In: Glob Chang Biol., 2013, 19, p. 1985-2000.

6. Gilardi G., Garibaldi A., Gullino M.L. Emerging pathogens as a consequence of globalization and climate change: leafy vegetables as a case study. In: Phytopathologia Mediterranea, 2018, 57, 1, p. 146-152

7. Jones L.M., Koehler A.K., Trnka M. et al. Climate change is predicted to alter the current pest status of Globodera pallida and G. rostochiensis in the United Kingdom. In: Glob Chang Biol., 2017, 23, p. 4497-4507.

8. Ma L., Qiao J., Kong X. et al. Effect of low temperature and wheat winter-hardiness on survival of Puccinia striiformis f. sp tritici under controlled conditions. In: PLOS One, 2015, 10:e0130691.

9. Margalef R. Perspectives in Ecological Theory. University of Chicago Press, Chicago, IL, 1968, p.111 
10. Reinhold K. Maternal effects and the evolution of behavioural and morphological characters: a literature review indicates importance of extended maternal care. In: J. of Heredity, 2002, 93 (6), p. 400-405.

11. Ritchie F., Bain R., Mcquilken M. Survival of sclerotia of Rhizoctonia solani AG3PT and effect of soil-borne inoculum density on disease development on potato. In: J Phytopathol., 2013, 161, p.180-189.

12. Velásquez A.C., Castroverde C.D.M., He S.H. Plant and pathogen warfare under changing climate conditions. In: Curr Biol., 2018, 21, 28(10), c. 619-634.

13. Wheeler T., von Braun J. Climate change impacts on global food security. In: Science, 2013, 341, p. 508-513.

14. Xu G., Yuan M., Ai C. et al. uORF-mediated translation allows engineered plant disease resistance without fitness costs. In: Nature, 2017, 545, p. 491-494

15. Youssuf A.M.H. Gherbawya, Thanaa A. Maghrabya, Yassmin M. Shebany. Seasonal variations of Fusarium species in wheat fields in Upper Egypt. In: Archives of Phytopathology and Plant Protection, 2006, 39(5), p. 365 - 377.

16. Билай В.И. Фузарии. Киев: Наукова думка, 1977. 422 с.

17. Методы экспериментальной микологии. Киев: Наукова думка, 1982, 550 с.

18. Радченко, И.Н. Проявление положительной трансгрессивной изменчивости по элементам продуктивности колоса у гибридов $\mathrm{F}_{2}$ озимой мягкой пшеницы. В: Селекция і насінництво. 2008, вип. 96, с. 72-79. 